Original article

\title{
Clinico-epidemiological profile of stroke patients admitted in a tertiary care Hospital of Assam
}

\author{
Bhupendra Narayan Mahanta*, Tulika Goswami Mahanta, Pronab Gogoi \\ Department of Medicine, Assam Medical College, Dibrugarh 786001, Assam, India
}

\section{A R T I C L E I N F O}

\section{Article history:}

Received 16 May 2017

Received in revised form 7 September 2017

Accepted 9 September 2017

Available online 11 September 2017

\begin{abstract}
A B S T R A C T
Problem considered: Stroke or Cerebrovascular Accident (CVA) is the leading cause of death and disability and is a major problem in most part of the world as reported by WHO.

Aims: To estimate the clinico-epidemiological profile of acute stroke cases admitted in Assam Medical College and Hospital.

Methods: All consecutive cases attending the study site were enrolled and studied with predesigned questionnaires after obtaining ethical clearance for this observational study. Predesigned pretested questionnaire was used to assess socio-demographic profile, behavioural risk factor, health care seeking behaviour, dietary history, clinical examination along with routine blood examination and CT Scan. Statistical analysis was done using rates, ratio, proportion and chi-square test.

Results: Out of 470 cases enrolled the response rate was $96 \%$. Average age was $54.3 \pm 13$ years with an average monthly income of Rs. 10,831. Majority were literate (76.4\%). Majority presented with haemorrhagic cerebro-vascular accidents (CVA) (287, 63.6\%), while 164 (36.4\%) had ischemic CVA. Significant difference in prevalence of haemorrhagic and ischemic CVA in younger age group $(p=0.001)$, lower socio-economic strata $(p=0.001)$, patient's place of stay during symptom onset $(p=0.048)$ and mode of transportation to hospital $(p=0.021)$ was seen. Clinical signs and symptoms of ischemic and haemorrhagic CVA showed significant difference in symptoms like change in consciousness $(p=0.000)$, weakness in face/limb $(p=0.022)$, dysphagia $(p=0.042)$, headache $(p=0.006)$, diabetes $(p=0.001)$, tobacco consumption $(\mathrm{p}=0.000)$ and alcohol consumption $(\mathrm{p}=0.000)$. MLR showed significant association of haemorrhagic stroke with high salt consumption and loss of consciousness.

Conclusion: haemorrhagic CVA constitutes a larger percentage of stroke subtypes on this side of the globe effecting poor to lower middle class. Proper strategy to prevent and treat haemorrhagic CVA in this part of the world is the need of the hour.
\end{abstract}

(C) 2017 Published by Elsevier, a division of RELX India, Pvt. Ltd on behalf of INDIACLEN.

\section{Introduction}

Stroke is defined by WHO as "rapidly developing clinical symptoms and signs of focal (at times global) disturbance of cerebral function with symptoms lasting more than 24 hours or leading to death with no apparent cause other than that of vascular origin." 1 Globally, CVA or stroke accounts for about $10 \%$ of all deaths, two-thirds of which occur in low income countries. ${ }^{2}$ In India, stroke is a leading cause of death and acquired adult disability. ${ }^{3-6}$ While exact estimates of the incidence and clinical consequence of stroke in India are unavailable, the epidemiological survey covering 52,577 people reported an estimated standardized prevalence of 545 per 100,000 , an annual incidence of 145 per

\footnotetext{
* Corresponding author.

E-mail address: drbnmahanta@gmail.com (B.N. Mahanta).
}

100,000 and a 1 -month case-fatality of $41 \%$, all rates exceeding those in North America and Europe. ${ }^{7}$ Accordingly, the social and economic consequences of stroke are proposed to be enormous, particularly when stroke occurs in the main income earner of a household. ${ }^{8}$

Among the stroke subtypes, cerebral ischemia and infarction constitute about $85-90 \%$ of the total stroke subtypes in western countries with only about $10-15 \%$ patients with cerebral haemorrhage. ${ }^{9}$ But contrary to the western population, hemorrhagic CVA constitutes a larger percentage of stroke subtypes on this side of the globe as seen in countries like Japan and China probably because of poorly controlled hypertension. ${ }^{10}$

Despite the obvious importance of stroke in India, our understanding of the epidemiology, natural history and clinical management of stroke remains grossly inadequate. ${ }^{11}$ Large scale acute coronary syndromes, where large observational studies have been completed in India (INTERHEART and CREATE-Registry), ${ }^{12-14}$ 
there have been no observational studies for stroke in North east region. Dibrugarh District is having 27\% tea garden population having high prevalence of cardiovascular risk factor like hypertension, high salt intake and tobacco consumption. ${ }^{15}$ The stroke registry of Assam Medical College caters the whole District population as it is the only referral centre for the District. The present study is therefore designed to estimate the clinico epidemiological and practice pattern of acute stroke cases admitted in Assam Medical College and Hospital and to maintain a stroke registry.

\section{Methods}

Assam Medical College is the only tertiary care hospital in Dibrugarh District of Assam catering a total population of 1.3 million. All consecutive patients with diagnosis of stroke who attended Assam Medical College within 14 days of occurrence of disease during 2013-2015, and who came from the state of Assam were interviewed and were enrolled in the study. Written informed consent was obtained from all participants. Predesigned, pretested schedule including socio-demographic profile, clinical history and examination was recorded. Anthropometric measurement was done in the form of weight, height, waist circumference, hip circumference etc. Dietary assessment was done using food frequency questionnaire. Radiological diagnosis of causes other than stroke, like meningitis, encephalitis, space occupying lesion etc. was excluded. Also metabolic causes of altered sensorium based on clinical or laboratory means were not included in the study. Unconsciousness or loss of consciousness was defined as a condition in which ability to maintain awareness of self and of the environmental stimuli. The institutional ethics committee of Assam Medical College cleared this observational study.

\subsection{Sample size calculation}

Taking proportion of first-ever stroke captured in Mumbai registry, $89.2 \%$, and $80.2 \%$ were ischemic strokes and $17.7 \%$ haemorrhagic strokes, ${ }^{10}$ with $95 \%$ CI for 2 tail distribution the required sample size is 468 .

Statistical analysis was done using rates, ratio and proportion and the difference in proportion was assessed by using chi square test and F-test.

\section{Results}

A total of 450 cases of strokes were enrolled, out of 470 CVA. So the response rate is $96 \%$. The age of the participants ranges from 18-87 years with an average of $54.3 \pm 13$ years (Fig. 1 ). Average

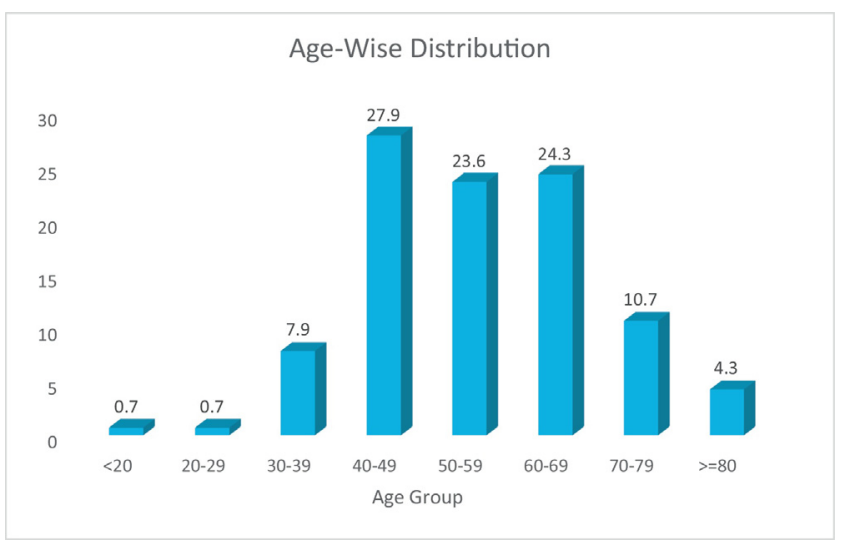

Fig. 1. Age wise distribution of stroke patients. family size of study participant was six. Average income is Rs. 10831. Majority of the study participants $83(75.8 \%)$ were between 40-69 years and Hindu by religion 135 (96.4\%). Majority were literate (76.4\%), while $23.6 \%$ were illiterate. $47.1 \%$ subjects were either unemployed or retired, while $33.6 \%$ were self-employed and only $19.3 \%$ were employed in any government or private concerns. Majority (55\%) were the earning member of the family. Regarding assets; $82.9 \%$ owned houses as property, while access to media in the form of phone or mobile was available in $48.6 \%$ cases. Most of the study participants (95.7\%) were from poor or lower middle class as per socio-economic classification. During occurrence of current event symptoms occurs at home in $88.6 \%$ while $7.9 \%$ were in workplace and $3.6 \%$ were alone at home. Ambulance services were availed by $82.1 \%$ of the sufferers for transportation, while $15.7 \%$ travelled by privately hired vehicle. In $75.7 \%$ cases the patient was first admitted to the Medical College, while in $24.3 \%$ cases the patient was referred from other hospital. The first consultation was with a general doctor in $87.9 \%$ cases and only $10 \%$ could get specialist advices like physician and $2.1 \%$ sufferers could not get access to any doctor (Table 1 ).

\subsection{Prehospital symptoms}

Majority presented with haemorrhagic shock (HS)(287, 63.6\%), while 164 (36.4\%) had ischemic shock (IS). Stroke was diagnosed as initial diagnosis in $94.7 \%$ cases. Stroke diagnosis was made at home in $3(0.7 \%)$ cases, while $256(62.2 \%)$ cases were diagnosed by first level health care provider and 158(37.1\%) were diagnosed in emergency medicine department. Ranking scale 1 week prior to event $(n=140)$ was ' 0 ' in $138(98.6 \%)$ cases, while ' 1 ' in $2(1.4 \%)$ cases. Ranking scale at admission was ' 3 ' in $17(12.1 \%$ ) cases and ' 4 ' in $55(39.3 \%)$ cases. History of transient ischemic attack $(n=176)$ was found in $9(5.1 \%)$ cases.

\subsection{Symptoms on presentation in hospital}

Change in consciousness was present in 257 (77.1\%) cases, while $193(42.9 \%)$ had no change of consciousness. Altered speech was present in 138 (30.7\%) cases, weakness of face/limb in 294 (65.3\%) cases, while dysphagia was present in $5(1.1 \%)$. Ocular/visual symptoms was found in 33(7.3\%) cases, vertigo/ataxia was evident in $16(3.6 \%)$ and sensory symptoms were present in 69 (15.3\%) cases. Headache was complained by 149 (33.1\%) cases.

\subsection{On clinical examination}

Mean $( \pm$ SD) SBP was $168( \pm 29)$ and DBP was $97( \pm 14)$. The mean heart rate $( \pm$ SD) was $80( \pm 9)$ beats/min, while average temperature was $96.6( \pm 8.0)$ degree F. Respiratory rate $( \pm S D)$ was $20.5( \pm 2.4) / \mathrm{min}$. Anthropometric examination shows average weight as $54.2 \pm 8.9 \mathrm{~kg}$, waist circumference (supine)$69.8 \pm 20.1 \mathrm{~cm}$ and hip circumference (supine) $-70.2 \pm 28.2 \mathrm{~cm}$.

\subsection{Regarding past medical history}

Hypertension was known in 163(36.2\%) cases, while 287(63.8\%) has either normal blood pressure or unknown status. Fifty two individual (11.6\%) were known diabetic, while $3(0.7 \%)$ had angina, $1(0.2 \%)$ had valvular heart disease, $4(0.9 \%)$ had atrial fibrillation and $2(0.4 \%)$ had past history of stroke.

\subsection{Behavioural risk factor}

Majority were current user of tobacco was 235(52.2\%), while 84 (18.7\%) were former user and 131 (19.1\%) had never used tobacco. 
Table 1

Socio-demographic profile of study participants.

\begin{tabular}{|c|c|c|c|}
\hline Demographic Profile & & $\mathrm{N}$ & Percentage \\
\hline \multirow[t]{2}{*}{ Gender } & Men & 277 & 61.6 \\
\hline & Women & 173 & 38.4 \\
\hline \multirow[t]{3}{*}{ Area of Residence } & Urban & 32 & 7.1 \\
\hline & Semi urban & 118 & 26.2 \\
\hline & Rural & 300 & 66.7 \\
\hline \multirow[t]{4}{*}{ Education status } & None & 104 & 23.1 \\
\hline & Primary School & 196 & 43.6 \\
\hline & High School & 140 & 31.1 \\
\hline & University & 10 & 2.2 \\
\hline \multirow[t]{4}{*}{ Occupational status } & Employed & 59 & 13.1 \\
\hline & Self employed & 115 & 25.6 \\
\hline & Unemployed & 236 & 52.4 \\
\hline & Retired & 40 & 8.9 \\
\hline \multirow[t]{4}{*}{ No of earning family members } & One & 233 & 51.8 \\
\hline & Two & 170 & 37.8 \\
\hline & 3 to 4 & 42 & 9.3 \\
\hline & 5 to 6 & 5 & 1.1 \\
\hline \multirow[t]{6}{*}{ Earning members in the family } & Patient & 84 & 18.7 \\
\hline & Spouse & 68 & 15.1 \\
\hline & Son/daughter & 156 & 34.7 \\
\hline & Patient \& son & 112 & 24.9 \\
\hline & Patient \& Spouse & 9 & 2 \\
\hline & Spouse \& Son & 21 & 4.7 \\
\hline \multirow[t]{2}{*}{ Owned Car } & No & 444 & 98.7 \\
\hline & Yes & 6 & 1.3 \\
\hline \multirow[t]{2}{*}{ Motorcycle/scooter } & No & 309 & 68.7 \\
\hline & Yes & 141 & 31.3 \\
\hline \multirow[t]{2}{*}{ Bicycle } & No & 78 & 17.3 \\
\hline & Yes & 372 & 82.7 \\
\hline \multirow[t]{2}{*}{ House } & No & 132 & 29.3 \\
\hline & Yes & 318 & 70.7 \\
\hline \multirow[t]{2}{*}{ Computer } & No & 440 & 97.8 \\
\hline & Yes & 10 & 2.2 \\
\hline \multirow[t]{2}{*}{ Washing machine } & No & 446 & 99.1 \\
\hline & Yes & 4 & 0.9 \\
\hline \multirow[t]{2}{*}{ Telephone } & No & 276 & 61.3 \\
\hline & Yes & 174 & 38.7 \\
\hline \multirow[t]{2}{*}{ Refrigerator } & No & 425 & 94.4 \\
\hline & Yes & 25 & 5.6 \\
\hline \multirow[t]{2}{*}{ Agricultural vehicle } & No & 425 & 94.4 \\
\hline & Yes & 25 & 5.6 \\
\hline \multirow[t]{2}{*}{ Land/property } & No & 340 & 75.6 \\
\hline & Yes & 110 & 24.4 \\
\hline \multirow[t]{2}{*}{ Tube well } & No & 207 & 46 \\
\hline & Yes & 243 & 54 \\
\hline \multirow[t]{3}{*}{ Socio economic status } & Upper middle class & 95 & 21.1 \\
\hline & Lower middle class & 295 & 65.6 \\
\hline & Poor & 60 & 13.3 \\
\hline
\end{tabular}

Current alcohol use was 150 (33.3\%), while 92 (20.4\%) were former user and majority 208 (46.2\%) had never consumed alcohol.

\subsection{Knowledge about stroke}

Majority 371(82.4\%) had no idea about suddenness of onset of stroke. Altered speech as a symptom of stroke was not known to
$322(71.6 \%)$ cases, while sudden onset of severe headache as probable symptoms was known to only 120 (26.7\%) cases. Unawareness about sudden onset of weakness was found in 300 (66.7\%) cases, similarly sudden onset of shortness of breathing was not known to 353 (78.4\%) cases. Sudden onset of trouble seeing with one or both eye was known to only 32 (7.1\%) cases. Only 7 (1.6\%) cases know about most of the symptoms of stroke.

\subsection{Knowledge about known risk factors of stroke}

Diabetes as a risk factor of stroke was known to 34 (7.6\%), while obesity as a risk factor was known to $88(19.6 \%)$, heart disease as risk factor was known to $113(25.1 \%)$. Regarding behavioural risk factor alcohol consumption was considered as risk factor by 78 (17.3\%), while smoking is considered as risk factor by $64(14.2 \%)$. Tea was considered as risk factor by $91(20.9 \%)$, while high cholesterol 94(20.9\%), stress 112 (24.9\%), high blood pressure 138 (30.7\%), pollution $107(23.8 \%)$, lack of exercise $85(18.9 \%)$. Amongst the studied participants 221 (49.1\%) had no idea about factors which increases risk of stroke.

\subsection{Dietary history}

Dietary history using 24 hour recall method shows 445(98.9\%) consumes rice as staple food, while majority takes weekly meat 306(68\%), fish 392(87.1\%), egg 368(81.8\%). Refined pulses was consumed daily by $186(41.3 \%)$ and weekly by $183(40.7 \%)$. Dairy consumption was very rare in 203 (67.3\%), only 116(25.8\%) consumes milk daily and 31 (6.9\%) consumes weekly. Extra salt intake and salty snake use was common (daily) in 102 (22.7\%), while 158 (35.1\%) consumes weekly. Sweet and sugar consumption was done daily in $8(1.8 \%)$ and $68(15.1 \%)$ cases, while weekly in 253 (56.2\%) and 213 (47.3\%) cases. Fruits and nuts consumption is very rare as 51 (11.3\%) and 15 (3.3\%) consumes it respectively. Only 148 (32.9\%) consumes green leafy vegetables daily, while $274(60.9 \%)$ consumes weekly. Extra salt use is meal was told by 206(45.8\%) cases, while $32(7.1 \%)$ consumes salted tea.

CT Scan showed $30 \%(135)$ cases as ischemic stroke, while intracerebral haemorrhage was found in 69.3\% (312) and subarachnoid haemorrhage was found in $0.1 \%$ (3) cases.

Determinant of ischemic and haemorrhagic stroke showed significantly different in prevalence of haemorrhagic and ischemic stroke in younger age group $(p=0.001)$ and those hailing from lower socio-economic strata $(p=0.001)$. There is significant difference of patient stay during symptom onset in haemorrhagic and ischemic stroke $(\mathrm{p}=0.048)$. Transport to hospital was also significantly different $(\mathrm{p}=0.021)$ amongst haemorrhagic and ischemic stroke. Diagnosis of stroke done as initially was also significantly higher in ischemic than haemorrhagic stroke ( $\mathrm{p}=0.064)$ (Table 2).

Clinical signs and symptoms of ischemic and haemorrhagic stroke showed significant difference in symptoms like change in consciousness $(p=0.000)$, weakness in face/limb $(p=0.022)$, dysphagia $(p=0.042)$, headache $(p=0.006)$, diabetes $(p=0.001)$, tobacco consumption $(\mathrm{p}=0.000)$ and alcohol consumption $(\mathrm{p}=0.000)$ (Table 3).

Dietary survey using food frequency questionnaire, showed consumption of meat ( $p=0.000)$, dairy product $(p=0.001)$, pickled vegetable $(p=0.012)$, sugar $(p=0.016)$, nuts $(p=0.008)$ and extra salt use with meal $(\mathrm{p}=0.048)$ was significantly different amongst ischemic and haemorrhagic stroke (Table 4).

Multiple logistic regression analysis showed significant association of haemorrhagic stroke with high salt consumption [AOR $1.715,95 \%$ CI $1.034-2.843, p=0.037]$ and loss of consciousness [AOR 2.946, 95\% CI 1.665-5.210, p=0.000] (Table 5). 
Table 2

Comparison of determinant of ischemic and haemorrhagic stroke.

\begin{tabular}{|c|c|c|c|c|c|}
\hline \multicolumn{2}{|l|}{ Variable } & \multicolumn{2}{|c|}{ Type of stroke } & \multirow[t]{2}{*}{ chi-square } & \multirow[t]{2}{*}{ p-value } \\
\hline & & $\begin{array}{c}\text { Ischemic stroke } \\
\mathrm{N}(\%)\end{array}$ & $\begin{array}{l}\text { Haemorrhagic stroke } \\
\mathrm{N}(\%)\end{array}$ & & \\
\hline \multirow[t]{2}{*}{ Gender } & Male & $94(33.9)$ & $183(66.1)$ & 1.959 & 0.162 \\
\hline & Female & $70(40.5)$ & $103(59.5)$ & & \\
\hline \multirow[t]{3}{*}{ Area of residence } & Urban & $16(50.0)$ & $16(50.0)$ & 5.39 & 0.068 \\
\hline & Semi urban & $49(41.5)$ & $69(58.5)$ & & \\
\hline & Rural & $99(33.0)$ & $201(67.0)$ & & \\
\hline \multirow[t]{6}{*}{ Age group } & $<30$ & $0(0.0)$ & $4(100.0)$ & 19.796 & 0.001 \\
\hline & $30-39$ & $8(30.8)$ & $18(69.2)$ & & \\
\hline & $40-49$ & $34(32.4)$ & $71(67.6)$ & & \\
\hline & $50-59$ & $37(31.4)$ & $81(68.6)$ & & \\
\hline & $60-69$ & $34(32.4)$ & $71(67.6)$ & & \\
\hline & $\geqq 70$ & $51(55.4)$ & $41(44.6)$ & & \\
\hline \multirow[t]{4}{*}{ Education status } & None & $36(34.6)$ & $68(65.4)$ & 1.224 & 0.747 \\
\hline & Primary School & $69(35.2)$ & $127(64.8)$ & & \\
\hline & High School & $56(40.0)$ & $84(60.0)$ & & \\
\hline & University & $3(30.0)$ & $7(70.0)$ & & \\
\hline \multirow[t]{4}{*}{ Occupational status } & Employed & $19(32.2)$ & $40(67.8)$ & 5.121 & 0.163 \\
\hline & Self employed & $40(34.8)$ & $75(65.2)$ & & \\
\hline & Unemployed & $84(35.6)$ & $152(64.4)$ & & \\
\hline & Retired & $21(52.5)$ & $19(47.5)$ & & \\
\hline \multirow[t]{3}{*}{ Socio economic status } & Upper middle class & $49(51.6)$ & $46(48.4)$ & 13.613 & 0.001 \\
\hline & Lower middle class & $100(33.9)$ & $195(66.1)$ & & \\
\hline & Poor & $15(25.0)$ & $45(75.0)$ & & \\
\hline \multirow[t]{4}{*}{ Patient during symptom onset } & Alone at home & $42(48.8)$ & $44(51.2)$ & 7.884 & 0.048 \\
\hline & At home with surrogate & $98(33.4)$ & $195(66.6)$ & & \\
\hline & At workplace & $23(35.4)$ & $42(64.6)$ & & \\
\hline & Others & $1(16.7)$ & $5(83.3)$ & & \\
\hline \multirow[t]{4}{*}{ Transport to hospital } & Ambulance & $131(35.6)$ & $237(64.4)$ & 9.687 & 0.021 \\
\hline & Own transport & $6(60.0)$ & $4(40.0)$ & & \\
\hline & Privately hired transport & $23(33.8)$ & $45(66.2)$ & & \\
\hline & Public transport & $4(100.0)$ & $0(0.0)$ & & \\
\hline \multirow[t]{2}{*}{ Was stroke an initial diagnosis } & No & $13(54.2)$ & $11(45.8)$ & 3.438 & 0.064 \\
\hline & Yes & $151(35.4)$ & $275(64.6)$ & & \\
\hline \multirow[t]{2}{*}{ Rankin scale 1 week prior to event $(n=140)$} & 0 & $40(29.0)$ & $98(71.0)$ & 4.734 & 0.030 \\
\hline & 1 & $2(100.0)$ & $0(0.0)$ & & \\
\hline \multirow[t]{3}{*}{ Rankin scale at admission $(n=140)$} & 3 & $8(47.1)$ & $9(52.9)$ & 2.781 & 0.249 \\
\hline & 4 & $16(29.1)$ & $39(70.9)$ & & \\
\hline & 5 & $18(26.5)$ & $50(73.5)$ & & \\
\hline
\end{tabular}

\section{Discussion}

Age of onset of stroke is highest in 40-49 years, which is the most productive period of life. Haemorrhagic stroke is the commonest occurrence in our study. Our population is younger and mostly from lower socio-economic strata. Change in consciousness (77.1\%), weakness of face/limb (65.3\%), Headache (33.1\%), altered speech (30.7\%), sensory symptoms (15.3\%), Ocular/visual symptoms (7.3\%), vertigo/ataxia (3.6\%), dysphagia (1.1\%) are commonest symptoms during presentation of patients in hospital. Mean blood pressure was higher $168 / 97 \mathrm{~mm}$ of $\mathrm{Hg}$ than the cut off value with $36.2 \%$ known hypertensive, while $11.6 \%$ were known diabetic.

Stroke or Cerebrovascular Accident (CVA) is a frequent cause of death and disability and is a major problem in most part of the world. ${ }^{4}$ After heart disease and carcinoma, stroke is the third leading cause of death in developed countries. ${ }^{4}$ Of patients with first-ever stroke captured in the Mumbai registry, CT imaging was done in $89.2 \%$, and $80.2 \%$ were ischemic strokes and $17.7 \%$ hemorrhagic strokes. ${ }^{10}$ In the Trivandrum registry, $69.7 \%$ of patients underwent imaging. Of those, $83.6 \%$ were ischemic strokes, $11.6 \%$ intracerebral haemorrhages, and $4.8 \%$ subarachnoid haemorrhages, respectively. ${ }^{16}$ There were more strokes of undetermined type in patients enrolled from the rural communities because of a lack of neuroimaging information (31.2\%). ${ }^{11}$ In a hospital based retrospective study done in Kolkata, reported approximately equal no of haemorrhagic (399) and ischemic stroke (393) in 792 patients of strokes who underwent CT scan. Hypertension was observed in $77.3 \%$ of ICH cases. The striking finding of this study was a remarkably high number of ICH among the admitted patients. ${ }^{17}$ In another study done in Bangalore found ischaemic stroke, most frequent (73.8\%) like in many other study. ${ }^{18}$ The possible cause of very high haemorrhagic stroke (69.3\%) in our study population may be a feature of lifestyle rather than genetics 
Table 3

Difference in clinical signs and symptoms of ischemic and haemorrhagic stroke.

\begin{tabular}{|c|c|c|c|c|c|}
\hline \multicolumn{2}{|c|}{ Variable } & \multicolumn{2}{|c|}{ Type of stroke } & \multirow[t]{2}{*}{ chi-square } & \multirow[t]{2}{*}{ p-value } \\
\hline & & $\begin{array}{c}\text { Ischemic stroke } \\
\mathrm{N}(\%)\end{array}$ & $\begin{array}{c}\text { Haemorhagic stroke } \\
\mathrm{N}(\%)\end{array}$ & & \\
\hline \multirow[t]{2}{*}{ History of TIA $(n=176)$} & No & $60(35.9)$ & $107(64.1)$ & 0.025 & 0.874 \\
\hline & Yes & $3(33.3)$ & $6(66.7)$ & & \\
\hline \multirow[t]{2}{*}{ Change in consciousness } & No & $96(49.7)$ & $97(50.3)$ & 25.794 & 0.000 \\
\hline & Yes & $68(26.5)$ & $189(73.5)$ & & \\
\hline \multirow[t]{2}{*}{ Speech } & No & $122(39.1)$ & $190(60.9)$ & 3.104 & 0.078 \\
\hline & Yes & $42(30.4)$ & $96(69.9)$ & & \\
\hline \multirow[t]{2}{*}{ Weakness in face/limbs } & No & $68(43.6)$ & $88(56.4)$ & 5.263 & 0.022 \\
\hline & Yes & $96(32.7)$ & $198(67.3)$ & & \\
\hline \multirow[t]{2}{*}{ Dysphagia } & No & $160(36.0)$ & $285(64.0)$ & 4.141 & 0.042 \\
\hline & Yes & $4(80.0)$ & $1(20.0)$ & & \\
\hline \multirow[t]{2}{*}{ Ocular/visual symptoms } & No & $151(36.2)$ & $266(63.8)$ & 0.134 & 0.715 \\
\hline & Yes & $13(39.4)$ & $20(60.6)$ & & \\
\hline \multirow[t]{2}{*}{ Headache } & No & $123(40.9)$ & $178(59.1)$ & 7.665 & 0.006 \\
\hline & Yes & $41(27.5)$ & $108(72.5)$ & & \\
\hline \multirow[t]{2}{*}{ Hypertension } & No & $111(38.7)$ & $176(61.3)$ & 1.703 & 0.192 \\
\hline & Yes & $53(32.5)$ & $110(67.5)$ & & \\
\hline \multirow[t]{2}{*}{ Diabetes } & No & $134(33.7)$ & $264(66.3)$ & 11.46 & 0.001 \\
\hline & Yes & $30(57.7)$ & $22(42.3)$ & & \\
\hline \multirow[t]{2}{*}{ Ischemic heart Angina } & No & $163(36.5)$ & $284(63.5)$ & 0.013 & 0.911 \\
\hline & Yes & $1(33.3)$ & 2 966.7) & & \\
\hline \multirow[t]{2}{*}{ Atrial Fib } & No & $161(36.1)$ & $285(63.9)$ & 2.590 & 0.108 \\
\hline & Yes & $3(75.1)$ & $1(25.0)$ & & \\
\hline \multirow[t]{2}{*}{ Stroke } & No & $163(36.4)$ & $285(63.6)$ & 0.159 & 0.690 \\
\hline & Yes & $1(50.0)$ & $1(50.0)$ & & \\
\hline \multirow[t]{3}{*}{ Tobacco consumption } & Never used & $52(39.7)$ & $79(60.3)$ & 19.855 & 0.000 \\
\hline & Formerly used & $46(54.8)$ & $38(45.2)$ & & \\
\hline & Currently used & $66(28.1)$ & 169 (71.9) & & \\
\hline \multirow[t]{3}{*}{ Alcohol } & Never used & $82(39.4)$ & $126(60.6)$ & 18.124 & 0.000 \\
\hline & Formerly used & $46(50.0)$ & $46(50.0)$ & & \\
\hline & Currently used & $36(24.0)$ & $114(76.0)$ & & \\
\hline
\end{tabular}

and possibly linked with economic transition of the general population. Das, S. et al from eastern India also demonstrated high proportion of cerebral haemorrhage in the Eastern Indian community than in Western countries. ${ }^{19}$ Our population is nearly similar with the population in West Bengal with near similar food habits showing higher occurrence of haemorrhagic stroke.

Current Tobacco use was common (52.2\%) while $33.3 \%$ were current alcohol user. There is reports of rapid rise in tobacco and alcohol related disease in people of Assam. Available records indicate a higher prevalence of hypertension among certain groups (example tea garden workers) of population in comparison to other studies. ${ }^{20}$ Alcohol use is woven into religious rituals and the cultural fabric of tea worker society. This population has a low prevalence of overweight/obesity, and higher physical activity levels as compared to other states of India while they have high prevalence of tobacco consumption mainly smokeless tobacco use in their community. ${ }^{15}$

Knowledge about risk factors of stroke was also very poor as only $7.6 \%$ knows diabetes as risk factor while $19.6 \%$ considers obesity as risk factor. Stress is considered as risk factor by $24.9 \%$, while smoking as risk factor was considered by $14.2 \%$, pollution by
$23.8 \%$, lack of exercise by $18.9 \%$ and $49.1 \%$ had no idea about factors which increases risk of stroke.

Milk or dairy product consumption, fruits and vegetable consumption was very less, while staple food is rice and $45.8 \%$ consumes extra salt with meal and $7.1 \%$ consumes salted tea. Dietary survey using food frequency questionnaire, showed consumption of meat, dairy product, pickled vegetable, sugar, nuts and extra salt use with meal was significantly different amongst ischemic and haemorrhagic stroke.The overall global target is a 30\% reduction by 2025 in global average population salt consumption. This is the only nutrition-specific target and a core component of the GlobalAction Plan for the Prevention and Control of Noncommunicable Diseases 2013-2020, which aims to achieve a $25 \%$ reduction in premature mortality from avoidable noncommunicable diseases (NCDs) by $2025 .{ }^{21}$ Observational studies, shown that nutritional intake can alter stroke risk factors; but most interventional studies so far failed to achieve meaningful clinical outcomes. We therefore do not have much evidence that dietary or lifestyle interventions in absence of pharmacological therapy can effectively prevent stroke. It may not however be that such interventions will not work, but that dose of intervention was 
Table 4

Comparison of dietary pattern amongst persons having ischemic and haemorrhagic stroke.

\begin{tabular}{|c|c|c|c|c|c|}
\hline \multicolumn{2}{|c|}{ Variable } & \multicolumn{2}{|c|}{ Type of stroke } & \multirow[t]{2}{*}{ chi-square } & \multirow[t]{2}{*}{ p-value } \\
\hline & & $\begin{array}{c}\text { Ischemic stroke } \\
\mathrm{N}(\%)\end{array}$ & $\begin{array}{c}\text { Haemorhagic stroke } \\
\mathrm{N}(\%)\end{array}$ & & \\
\hline Meat & $\begin{array}{l}<1 \text { per month } \\
\text { Monthly } \\
\text { Weekly } \\
\text { Daily }\end{array}$ & $\begin{array}{l}9(64.3) \\
62(49.6) \\
92(30.1) \\
1(20.0)\end{array}$ & $\begin{array}{l}5(35.7) \\
63(50.4) \\
214(69.9) \\
4(80.0)\end{array}$ & 19.985 & 0.000 \\
\hline Fish & $\begin{array}{l}<1 \text { per month } \\
\text { Monthly } \\
\text { Weekly } \\
\text { Daily }\end{array}$ & $\begin{array}{l}1(50.0) \\
24(52.2) \\
134(34.2) \\
5(50.0)\end{array}$ & $\begin{array}{l}1(50.0) \\
22(47.8) \\
258(65.8) \\
5(50.0)\end{array}$ & 6.731 & 0.081 \\
\hline Eggs & $\begin{array}{l}<1 \text { per month } \\
\text { Monthly } \\
\text { Weekly } \\
\text { Daily }\end{array}$ & $\begin{array}{l}8(40.0) \\
13(33.3) \\
135(36.7) \\
8(34.8)\end{array}$ & $\begin{array}{l}12(60.0) \\
26(66.7) \\
233(63.3) \\
15(65.2)\end{array}$ & 0.309 & 0.958 \\
\hline Dairy products & $\begin{array}{l}<1 \text { per month } \\
\text { Monthly } \\
\text { Weekly } \\
\text { Daily }\end{array}$ & $\begin{array}{l}69(30.4) \\
22(28.9) \\
13(41.9) \\
60(51.7)\end{array}$ & $\begin{array}{l}158(69.6) \\
54(71.1) \\
18(58.1) \\
56(48.3)\end{array}$ & 17.525 & 0.001 \\
\hline Soy sauce, fish sauce & $\begin{array}{l}<1 \text { per month } \\
\text { Monthly } \\
\text { Weekly }\end{array}$ & $\begin{array}{l}149(35.8) \\
8(34.8) \\
7(63.6)\end{array}$ & $\begin{array}{l}267(64.2) \\
15(65.2) \\
4(36.4)\end{array}$ & 3.61 & 0.165 \\
\hline Salty foods, snacks & $\begin{array}{l}<1 \text { per month } \\
\text { Monthly } \\
\text { Weekly } \\
\text { Daily }\end{array}$ & $\begin{array}{l}50(44.6) \\
32(41.0) \\
50(31.6) \\
32(31.4)\end{array}$ & $\begin{array}{l}62(55.4) \\
46(59.0) \\
108(68.4) \\
70(68.6)\end{array}$ & 6.661 & 0.084 \\
\hline Pickled vegetables & $\begin{array}{l}<1 \text { per month } \\
\text { Monthly } \\
\text { Weekly } \\
\text { Daily }\end{array}$ & $\begin{array}{l}45(29.4) \\
39(33.6) \\
80(44.9) \\
0(0.0)\end{array}$ & $\begin{array}{l}108(70.6) \\
77(66.4) \\
98(55.1) \\
3(100.0)\end{array}$ & 10.938 & 0.012 \\
\hline Sugar & $\begin{array}{l}<1 \text { per month } \\
\text { Monthly } \\
\text { Weekly } \\
\text { Daily }\end{array}$ & $\begin{array}{l}14(45.2) \\
38(27.5) \\
91(42.7) \\
21(30.9)\end{array}$ & $\begin{array}{l}17(54.8) \\
100(72.5) \\
122(57.3) \\
47(69.1)\end{array}$ & 10.278 & 0.016 \\
\hline Legumes & $\begin{array}{l}<1 \text { per month } \\
\text { Monthly } \\
\text { Weekly } \\
\text { Daily }\end{array}$ & $\begin{array}{l}1(100.0) \\
22(31.0) \\
28(28.0) \\
113(40.6)\end{array}$ & $\begin{array}{l}0(0.0) \\
49(69.0) \\
72(72.0) \\
165(59.4)\end{array}$ & 7.856 & 0.049 \\
\hline Nuts & $\begin{array}{l}<1 \text { per month } \\
\text { Monthly } \\
\text { Weekly } \\
\text { Daily }\end{array}$ & $\begin{array}{l}86(34.5) \\
69(45.3) \\
10(20.0) \\
0(0.0)\end{array}$ & $\begin{array}{l}163(65.5) \\
82(54.7) \\
40(80.0) \\
1(100.0)\end{array}$ & 11.918 & 0.008 \\
\hline Extra salt used in meal & $\begin{array}{l}\text { No } \\
\text { Yes }\end{array}$ & $\begin{array}{l}99(40.6) \\
65(31.6)\end{array}$ & $\begin{array}{l}145(59.4) \\
141(68.4)\end{array}$ & 3.924 & 0.048 \\
\hline Drink salted tea & $\begin{array}{l}\text { No } \\
\text { Yes }\end{array}$ & $\begin{array}{l}152(36.4) \\
12(37.5)\end{array}$ & $\begin{array}{l}266(63.6) \\
20(62.5)\end{array}$ & 0.017 & 0.898 \\
\hline
\end{tabular}

insufficient, or that knowledge of how to make these interventions achieve a clinically significant impact is still deficient. ${ }^{22}$

Determinant of ischemic and haemorrhagic stroke showed significant difference in prevalence of haemorrhagic and ischemic stroke in younger age group and those from lower socio-economic strata. Transport to hospital was also significantly different amongst haemorrhagic and ischemic stroke. Diagnosis of stroke done as initially was also significantly higher in ischemic than haemorrhagic stroke.

Clinical signs and symptoms of ischemic and haemorrhagic stroke showed significant difference in symptoms like change in consciousness, weakness in face/limb, dysphagia, headache, diabetes, tobacco consumption and alcohol consumption. Other study also show association with high tobacco consumption amongst lower socio-economic class. ${ }^{23}$ Indian Government, launched National Program for Prevention\& Control of Cancer, Diabetes, Cardiovascular Diseases and Stroke (NPCDCS) to address high prevalence of non-communicable diseases (NCDs). ${ }^{24}$ Risk factor control requires, multidisciplinary approach, which includes approaching social determinants of health, health-care financing, improving medical education, and health system strengthening. ${ }^{25}$

Determination of stroke subtypes by MRI was not done and this may be considered as a limnitation of the study. Dietary assessment was done based on food frequency questionnaire, 
Table 5

Multiple logistic regression analysis of risk factors with types of stroke.

\begin{tabular}{|c|c|c|c|c|c|c|}
\hline Variable & & $\mathrm{N}(\%)$ & PR (\%) & AOR & $95 \% \mathrm{CI}$ & p-value \\
\hline \multirow[t]{5}{*}{ Age group } & $30-39$ & $30(6.7)$ & $22(73.3)$ & Ref. & & \\
\hline & $40-49$ & $105(23.3)$ & $71(67.6)$ & 0.681 & $0.251-1.848$ & 0.450 \\
\hline & $50-59$ & $118(26.2)$ & $81(24.8)$ & 0.744 & $0.272-2.039$ & 0.565 \\
\hline & $60-69$ & $105(23.3)$ & $71(67.6)$ & 0.761 & $0.279-2.073$ & 0.593 \\
\hline & $\geqq 70$ & $92(20.4)$ & $41(44.6)$ & 0.276 & $0.100-0.767$ & 0.013 \\
\hline \multirow[t]{3}{*}{ Socio economic status } & Upper middle class & $95(21.1)$ & $46(48.4)$ & Ref. & & \\
\hline & Lower middle class & $295(65.6)$ & $195(66.1)$ & 1.416 & $0.761-2.635$ & 0.272 \\
\hline & Poor & $60(13.3)$ & $45(75.0)$ & 1.141 & $0.431-3.022$ & 0.791 \\
\hline \multirow[t]{4}{*}{ Patient during symptom onset } & Alone at home & $86(19.1)$ & $44(51.2)$ & Ref. & & \\
\hline & At home with surrogate & $293(65.1)$ & $195(66.6)$ & 0.842 & $0.363-1.951$ & 0.688 \\
\hline & At workplace & $65(14.4)$ & $42(64.6)$ & 1.366 & $0.622-3.001$ & 0.473 \\
\hline & Others & $6(1.3)$ & $5(83.3)$ & 4.742 & $0.410-54.806$ & 0.213 \\
\hline \multirow[t]{2}{*}{ Change in consciousness } & No & 193 (42.9) & $97(50.3)$ & Ref. & & \\
\hline & Yes & $257(57.1)$ & $189(73.5)$ & 2.946 & $1.665-5.210$ & 0.000 \\
\hline \multirow[t]{2}{*}{ Weakness in face/limbs } & No & $156(34.7)$ & $88(56.4)$ & Ref. & & \\
\hline & Yes & $294(65.3)$ & $198(67.3)$ & 1.179 & $0.696-1.998$ & 0.540 \\
\hline \multirow[t]{2}{*}{ Dysphagia } & No & $445(98.9)$ & $285(64.0)$ & Ref. & & \\
\hline & Yes & $5(1.1)$ & $1(20.0)$ & 0.197 & $0.016-2.487$ & 0.209 \\
\hline \multirow[t]{2}{*}{ Headache } & No & $301(66.9)$ & $178(59.1)$ & Ref. & & \\
\hline & Yes & $149(33.1)$ & $108(72.5)$ & 1.19 & $0.605-2.341$ & 0.615 \\
\hline \multirow[t]{2}{*}{ Diabetes } & No & $398(88.4)$ & $264(66.3)$ & Ref. & & \\
\hline & Yes & $52(11.6)$ & $22(42.3)$ & 0.574 & $0.287-1.148$ & 0.116 \\
\hline \multirow[t]{3}{*}{ Tobacco history } & Never used & $131(29.1)$ & $79(27.6$ & Ref. & & \\
\hline & Formerly used & $84(18.7)$ & $38(45.2)$ & 0.633 & $0.261-1.533$ & 0.311 \\
\hline & Currently used & $235(52.2$ & 169 (71.9) & 1.299 & $0.665-2.537$ & 0.444 \\
\hline \multirow[t]{3}{*}{ Alcohol } & Never used & $208(46.2)$ & $126(60.6)$ & Ref. & & \\
\hline & Formerly used & $92(20.4$ & $46(50.0)$ & 0.904 & $0.407-2.008$ & 0.805 \\
\hline & Currently used & $150(33.3)$ & $114(76.0)$ & 1.152 & $0.599-2.215$ & 0.672 \\
\hline \multirow[t]{4}{*}{ Meat } & $<1$ per month & $14(3.1)$ & $5(35.7)$ & Ref. & & \\
\hline & Monthly & $125(27.8)$ & $63(50.4)$ & 0.771 & $0.186-3.191$ & 0.720 \\
\hline & Weekly & $306(68.0)$ & $214(69.9)$ & 1.583 & $0.405-6.187$ & 0.509 \\
\hline & Daily & $5(1.1)$ & $4(80.0)$ & 2.530 & $0.171-37.364$ & 0.499 \\
\hline \multirow[t]{4}{*}{ Dairy products } & $<1$ per month & $227(50.4)$ & $158(69.6)$ & Ref. & & \\
\hline & Monthly & $76(16.9)$ & $54(71.1)$ & 0.650 & $0.291-1.449$ & 0.292 \\
\hline & Weekly & $31(6.9)$ & $18(58.1)$ & 0.860 & $0.342-2.165$ & 0.749 \\
\hline & Daily & $116(25.8)$ & $56(48.3)$ & 2.045 & $0.731-5.717$ & 0.173 \\
\hline \multirow[t]{3}{*}{ Pickled vegetables } & $<1$ per month & $153(34.0)$ & $108(70.6)$ & Ref. & & \\
\hline & Monthly & $116(25.8)$ & $77(66.4)$ & 1.243 & $0.655-2.358$ & 0.506 \\
\hline & Weekly & $181(40.2)$ & $101(55.8)$ & 0.936 & $0.479-1.827$ & 0.845 \\
\hline \multirow[t]{4}{*}{ Sugar } & $<1$ per month & $31(6.9)$ & $17(54.8)$ & Ref. & & \\
\hline & Monthly & $138(30.7)$ & $100(72.5)$ & 2.447 & $0.886-6.759$ & 0.084 \\
\hline & Weekly & $213(47.3)$ & $122(57.3)$ & 1.459 & $0.572-3.723$ & 0.429 \\
\hline & Daily & $68(15.1)$ & $47(16.4)$ & 2.158 & $0.757-6.157$ & 0.150 \\
\hline \multirow[t]{2}{*}{ Extra salt used in meal } & No & $206(45.8)$ & $141(68.4)$ & Ref. & & \\
\hline & Yes & $244(54.2)$ & $145(59.4)$ & 1.715 & $1.034-2.843$ & 0.037 \\
\hline
\end{tabular}

which is a standard procedure but subject to some recall bias. There is a need to do further analytical study like case control study for better evidence generation.

\section{Conclusion}

Haemorrhagic CVA constitutes a larger percentage of stroke subtypes on this part of the globe effecting poor to lower middle socio-economic class. Proper strategy to prevent and treat hemorrhagic stroke in this part of the world is the need of the hour. Control of risk factors require multidisciplinary approach, which include approaching social determinants of health, healthcare financing, improving medical education, and health system strengthening.

\section{References}

1. Hatano S. Experience from a multicentre stroke register: a preliminary report. Bulletin WHO. 1976;54:541-553.

2. World Health Organization. The world health report; changing history. Geneva: WHO; 2004:2004.

3. Murray CJL, Lopez AD. Global health statistics. global burden of disease and injuries series. Boston (MA): Harvard School of Public Health; 1996. 
4. World Health Organization. The world health report 2002; reducing risks, promoting life. Geneva: WHO; 2004.

5. Prabhakaran D, Yusuf S, Mehta S, Pogue J, Avenzum A, Budaj A, et al. Two year outcome in patients admitted with non ST elevation acute coronary syndrome; results of OASIS registry 1and 2. Indian Heart J. 2005;57:217-225.

6. Misra A. Overnutrition and nutritional deficiency contributes to metabolic syndrome and atherosclerosis in Indians. Nutrition. 2002;18:702-703.

7. Reddy KS. 2002; Cardiovascular diseases in developing countries; dimensions, determinants, dynamics and directions for public health action.

8. Hazarika NC, Biswas D, Narayan K, Kalita HC, Mahanta J. Hypertension and its risk factor in Tea garden workers of Assam. Natl Med J India. 2002;

9. Bamford J, Sandercock P, Dennis M et al. A prospective study of acute cerebrovascular disease in the community. The Oxfordshirecommunity stroke project, 1981-86.

10. Dalal PM, Malik S, Bhattacharjee M, Trivedi ND, Vairale J, Bhat P, et al. Population-based stroke survey in Mumbai, India: Incidence and 28-day case fatality. Neuroepidemiology. 2008;31:254-261.

11. Reddy KS, Pravakaran D, Chaturvedi V, et al. Methods for establishing a Sentinel Surveillance System for Cardiovuscular Disease amongst Indian Industrial Population. Bulletin WHO. 2006;84(6).

12. Mahanta TG, Ahmed FU, Mahanta BN, Barua A. Prevalence of Hypertension and its risk factors amongst Tea Garden Community of Dibrugarh District of Assam. Indian J Public Health. 2008; January-March.

13. Ahmed FU, et al. Salt consumption pattern in India; an ICMR Task Force study Report; 1996.

14. www.who.int. WHO steps surveillance; last updated 14 November 2008.

15. Mahanta TG, Mahanta BN, Joshi R, GogoiP. Xavier D. Behavioural risk factors distribution of cardiovascular diseases and its association with normotension, prehypertension and hypertension amongst tea garden population in Dibrugarh district of Assam. Clin Epidemiol Glob Health. 2016;4(1):45-50.
16. Sridharan SE, Unnikrishnan JP, Sukumaran S, Sylaja PN, Nayak SD, Sarma PS, et al. Incidence, types, risk factors, and outcome of stroke in a developing country: The Trivandrum Stroke Registry. Stroke. 2009;40:1212-1218.

17. Banerjee TK, Choudhury D, Das A, Sekhar A, Roy D, Sen S. Analysis of hospitalbased stroke registry in a neurological centre in Kolkata. J Indian Med Assoc. 2005;103(December (12)):665-668.

18. Nagaraja D, Gururaj G, Girish N, Panda S, Roy AK, Sarma GRK, Srinivasa R, et al. Feasibility study of stroke surveillance: data from Bangalore, India. Indian J Med Res. 2009;396-403.

19. Banerjee TK, Das SK, et al. Fifty years of stroke researches in India. Ann Indian Acad Neurol. 2016;19(January-March (1)):1-8.

20. Medhi GK, Hazarika NC, Mahanta J. Tobacco and alcohol use among the youth of The agricultural tea industry in Assam, India. South East Asian J Trop Med Pub Health. 2006;37(3).

21. SHAKE. The Salt Habit; together lets beat NCD; 2008-2013 action plan for the global strategy for the prevention and control of noncommunicable diseases. Geneva: World Health Organization; 2016. accessed in October, 2016 http:// www.who.int

22. Huang Chen Ya. Nutrition and stroke. Asia Pac J Clin Nutr. 2007;16(Suppl. (1)):266-274.

23. Thankappan KR, Thresia CU. Tobacco use \& social status in Kerala. Indian J Med Res. 2007;126:300-308.

24. Ministry of Health and Family Welfare, Government of India. Annual report to the people on health 2014-15 (source http://www.mohfw.nic.in/.pdf. Accessed 9th Dec 2016).

25. Gupta R, Guptha S, Joshi R, Xavier D. Translating evidence into policy for cardiovascular disease control in India. Health Res Policy Syst. 2011;9:810.1186/ 1478-4505-9-8. 